\title{
Improved resistance to Eimeria acervulina infection in chickens due to dietary supplementation with garlic metabolites
}

\author{
Duk Kyung Kim ${ }^{1}$, Hyun S. Lillehoj ${ }^{1 *}$, Sung Hyen Lee ${ }^{1}$, Erik P. Lillehoj ${ }^{2}$ and David Bravo ${ }^{3}$ \\ ${ }^{1}$ Animal Parasitic Diseases Laboratory, United States Department of Agriculture, Animal and Natural Resources Institute, \\ Building 1040, BARC-East, Beltsville, MD 20705, USA \\ ${ }^{2}$ Department of Pediatrics, University of Maryland School of Medicine, Baltimore, MD 21201, USA \\ ${ }^{3}$ Pancosma SA, Geneva, Switzerland
}

(Submitted 1 September 2011 - Final revision received 25 January 2012 - Accepted 25 January 2012 - First published online 13 April 2012)

\begin{abstract}
The effects of a compound including the secondary metabolites of garlic, propyl thiosulphinate (PTS) and propyl thiosulphinate oxide (PTSO), on the in vitro and in vivo parameters of chicken gut immunity during experimental Eimeria acervulina infection were evaluated. In in vitro assays, the compound comprised of PTSO (67\%) and PTS (33\%) dose-dependently killed invasive E. acervulina sporozoites and stimulated higher spleen cell proliferation. Broiler chickens continuously fed from hatch with PTSO/PTS compound-supplemented diet and orally challenged with live E. acervulina oocysts had increased body weight gain, decreased faecal oocyst excretion and greater E. acervulina profilin antibody responses, compared with chickens fed a non-supplemented diet. Differential gene expression by microarray hybridisation identified 1227 transcripts whose levels were significantly altered in the intestinal lymphocytes of PTSO/PTS-fed birds compared with non-supplemented controls (552 up-regulated, 675 down-regulated). Biological pathway analysis identified the altered transcripts as belonging to the categories 'Disease and Disorder' and 'Physiological System Development and Function'. In the former category, the most significant function identified was 'Inflammatory Response', while the most significant function in the latter category was 'Cardiovascular System Development and Function'. This new information documents the immunologic and genomic changes that occur in chickens following PTSO/PTS dietary supplementation, which are relevant to protective immunity during avian coccidiosis.
\end{abstract}

Key words: Garlic: Propyl thiosulphinate oxide: Propyl thiosulphinate: Eimeria acervulina: Chickens: Microarray techniques

Garlic (Allium sativum) is a medicinal plant that has historically been used for the treatment and prevention of some diseases and has recently been shown to have antimicrobial, antitumour, antioxidant and immunostimulatory properties ${ }^{(1-4)}$. The pharmacological effects of garlic on cardiovascular disease (CVD) are mediated through the alteration of cholesterol and triglyceride (TAG) levels in the bloodstream $^{(5)}$. The medicinal effects of garlic are derived from its flavonoid and organosulphur components. Studies in mammalian systems have indicated that these active pharmacological components act on multiple intracellular signalling pathways. In chickens, garlic compounds have also been shown to lower cholesterol and exert immunomodulating and antimicrobial activities ${ }^{(6-9)}$. However, compared with human studies, there is relatively limited information on the use of phytonutrients in general, and garlic in particular, in poultry veterinary medicine.
In addition to its effects on the cardiovascular system, garlic has been suggested for the treatment of parasitoses and other intestinal diseases ${ }^{(10)}$. For example, crude extracts of garlic reduced or eliminated Hymenolepis, Aspiculuris, Histomonas and Eimeria parasites in animal models of infection ${ }^{(11-15)}$. Of these parasites, coccidia protozoa comprise a subclass of single-celled eukaryotic micro-organisms belonging to the phylum Apicomplexa and class Conoidasida. Coccidia of the genus Eimeria infect the intestinal epithelia of chickens, turkeys and some mammalian hosts.

The intestinal intraepithelial lymphocytes (IEL), the primary immune effector cells of the gut-associated lymphoid tissues, recognise and destroy pathogens that breach the intestinal epithelium $^{(16)}$. Chicken intestinal IEL are composed of two phenotypically and functionally distinct subpopulations, naturalkiller (NK) cells and T-lymphocytes ${ }^{(17)}$. In our previous studies, we have shown that IEL are the major effectors against coccidia parasites, Eimeria ${ }^{(18,19)}$. In chickens, disruption of the gut

Abbreviations: GAPDH, glyceraldehyde-3-phosphate dehydrogenase; HBSS, Hank's balanced salt solution; IEL, intraepithelial lymphocytes; NK, natural killer; PTS, propyl thiosulphinate; PTSO, propyl thiosulphinate oxide; RPMI, Roswell Park Memorial Institute; TLR, Toll-like receptor; TNFSF13B, TNF (ligand) superfamily member $13 \mathrm{~b}$.

* Corresponding author: Dr H. S. Lillehoj, fax +1 301504 5103, email hyun.lillehoj@ars.usda.gov 
epithelium during avian coccidiosis severely restricts the feed conversion efficiency during commercial poultry production. While in-feed anticoccidial drugs and antibiotic growth promoters can be used to mitigate some of the effects of avian coccidiosis, the emergence of drug-resistant parasites and legislative restrictions on the use of in-feed antibiotic growth promoters are driving the development of alternative disease control strategies for poultry production ${ }^{(20,21)}$. Because garlic has been shown to exert anticoccidial effects in mouse and rabbit infection models ${ }^{(14)}$, in the present study we evaluated the effects of a compound including garlic-derived secondary metabolites, propyl thiosulphinate (PTS) and propyl thiosulphinate oxide (PTSO), on intestinal immunity to E. acervulina.

\section{Materials and methods \\ Parasite cytotoxicity assay}

Freshly sporulated E. acervulina oocysts were disrupted with $0.5 \mathrm{~mm}$ glass beads for 5-7 s and the freed sporocysts were incubated for $45 \mathrm{~min}$ at $41^{\circ} \mathrm{C}$ in PBS containing $0.014 \mathrm{M}-$ taurodeoxycholic acid (Sigma) and $0 \cdot 25 \%$ trypsin (Sigma) to release infective sporozoites. Sporozoites were separated from debris by filtration, resuspended in Roswell Park Memorial Institute (RPMI)-1640 medium (Invitrogen), and isolated by centrifugation at $2100 \mathrm{~g}$ for $10 \mathrm{~min}$ at $4^{\circ} \mathrm{C}$. Isolated sporozoites $\left(1.0 \times 10^{6} / \mathrm{ml}\right)$ were incubated with PBS (negative control), $10 \mu \mathrm{g} / \mathrm{ml}$ of Garlicon $40^{\circledR}$ or $5.0 \mu \mathrm{g} / \mathrm{ml}$ of chicken purified recombinant NK-lysin (positive control) ${ }^{(22)}$ for 2 or $4 \mathrm{~h}$ at $4^{\circ} \mathrm{C}$, and viability was measured by trypan blue exclusion by counting a minimum of 100 sporozoites.

Garlicon $40{ }^{\circledR}$, a product containing $40 \%$ of a compound made of $67 \%$ of propyl thiosulphinate oxide (PTSO) and $33 \%$ of PTS, was provided by Pancosma S.A. The biosynthesis of PTS is made from propiin (S-propyl-L-cysteine sulphoxide), an amino acid derived from L-cysteine found in Allium species. The first step of the biosynthesis (of thiosulphinates) is the formation of the sulphenic acid associated (in this case propyl-1-sulphenic acid; $\mathrm{CH}_{3} \mathrm{CH}_{2} \mathrm{CH}_{2} \mathrm{SOH}$ ) plus pyruvate plus ammonia. However, these compounds (sulphenic acids) are highly reactive, so they immediately produce thiosulphinates by a condensation reaction. In the last step, heating PTS induces its dismutation in PTSO and propyldisulphide. Propyldisulphide can be oxidised and transformed to PTSO and the oxidation of PTS to PTSO is never totally completed. Therefore, the two molecules are generally present in commercial samples. Garlicon $40^{\circledR}$ was notated as PTSO/PTS in the present study.

\section{Spleen lymphocyte proliferation}

All experiments were approved by the Agricultural Research Service Institutional Animal Care and Use Committee. For the purpose of the experiment, 3-week-old Ross/Ross broiler chickens (Longenecker's Hatchery) were euthanised by cervical dislocation, and the spleens were removed and placed in Petri dishes with $10 \mathrm{ml}$ of Hank's balanced salt solution (HBSS) supplemented with 100 units/ml penicillin and $100 \mu \mathrm{g} / \mathrm{ml}$ streptomycin (Sigma). Cell suspensions were prepared by gently flushing through a cell strainer and lymphocytes were purified by density gradient centrifugation through Histopaque-1077 (Sigma). The cells were adjusted to $1.0 \times 10^{7}$ cells $/ \mathrm{ml}$ in RPMI-1640 medium without phenol red (Sigma) and supplemented with 10\% fetal bovine serum, $100 \mathrm{units} / \mathrm{ml}$ penicillin and $100 \mu \mathrm{g} / \mathrm{ml}$ streptomycin. Then, $100 \mu \mathrm{l} /$ well of the sample were added to ninety-six-well flat-bottomed plates containing $100 \mu \mathrm{l} /$ well of PTSO/PTS $(10,5,2 \cdot 5$, $1 \cdot 25,0.6$ or $0.3 \mu \mathrm{g} / \mathrm{ml}$ ) from Pancosma S.A., $5 \mu \mathrm{g} / \mathrm{ml}$ of concanavalin A (Sigma) as a positive control, or medium alone as a negative control. The cells were incubated at $41^{\circ} \mathrm{C}$ in a humidified incubator (Forma) with $5 \% \mathrm{CO}_{2}$ for $48 \mathrm{~h}$, and the cell numbers were measured using WST-8 (2-(2-methoxy-4-nitrophenyl)-3(4-nitrophenyl)-5-(2,4-disulphophenyl)-2H-tetrazolium, monosodium salt) (Dojindo Molecular Technologies) at $450 \mathrm{~nm}$ using a microplate spectrophotometer (Bio-Rad).

\section{Experimental animals and diets}

Broiler chickens (Ross/Ross, Longenecker's Hatchery) were randomly housed in Petersime starter brooder units and fed, from hatch, a standard diet alone (control) or a diet supplemented with $10 \cdot 0$ parts per million of PTSO/PTS. The composition of the standard diet was prepared as recommended by the National Research Council ${ }^{(23)}$. The PTSO/PTS dose was chosen based on preliminary dose-response experiments.

\section{Eimeria acervulina infection of chickens}

At $10 \mathrm{~d}$ post-hatch, the chickens were transferred to large hanging cages (two birds/cage) and were orally infected with $1.0 \times 10^{4}$ sporulated oocysts of E. acervulina. The remaining chickens were housed in neighbouring cages, but were uninfected. Body weights (twenty birds/group) were measured at 0 and $10 \mathrm{~d}$ post-infection. Faecal samples (twenty birds/group) were collected between 6 and $9 \mathrm{~d}$ postinfection, and oocyst numbers were determined using a McMaster chamber (HK Inc.) according to the formula ${ }^{(24)}$ : total oocysts $/$ bird $=$ oocyst count $\times$ dilution factor $\times$ (faecal sample volume/counting chamber volume)/2.

\section{Anti-profilin serum antibody assay}

Peripheral blood (four birds/group) was collected from uninfected and infected chickens at $10 \mathrm{~d}$ post-infection, and sera were prepared by centrifugation and analysed for anti-profilin antibody levels by ELISA. For this, ninety-six-well plates were coated overnight with $10 \mu \mathrm{g} /$ well of E. acervulina purified recombinant profilin protein as described ${ }^{(25)}$. The plates were washed with PBS containing 0.05\% Tween and blocked with PBS containing $1.0 \%$ bovine serum albumin (Sigma). Diluted sera at 1:50 were added (100 $\mu \mathrm{l} /$ well), incubated with agitation for $1 \mathrm{~h}$ at room temperature and washed with PBS containing $0.05 \%$ Tween. Bound antibody was detected with horseradish peroxidase-conjugated rabbit anti-chicken IgG (Sigma) and $3,3^{\prime}, 5,5^{\prime}$-tetramethylbenzidine substrate (Sigma) by measuring the optical density at $450 \mathrm{~nm}$. All samples were analysed in quadruplicate. 


\section{Microarray hybridisation}

Chicken intestinal IEL were isolated from the non-infected chickens at $14 \mathrm{~d}$ post-hatch as described ${ }^{(26)}$ and gene expression analysis was performed by microarray hybridisation. The intestinal jejunum was removed, cut longitudinally and washed three times with ice-cold HBSS. Then, the samples were incubated in HBSS containing $0.5 \mathrm{~mm}$-EDTA and 5\% fetal calf serum for $20 \mathrm{~min}$ at $37^{\circ} \mathrm{C}$ with constant swirling. Cells released into the supernatant were passed through nylon wool (Robbins Scientific), and washed twice with HBSS containing 5\% fetal calf serum. The IEL were purified by Percoll density gradient centrifugation and washed three times with HBSS containing $5 \%$ fetal calf serum.

In preliminary experiments, we determined that the percentage of CD45-positive IEL ranges from 45 to $70 \%$ depending upon the genetics, age and infection status of chickens used (data not shown). Total RNA (six birds/group) was isolated using Trizol (Invitrogen) and pooled in two samples with equal amount from three birds each. RNA were amplified using the Two-Color Quick Amp Labeling Kit (Agilent Technologies) with cyanine 3 (Cy3)- or Cy5-labelled CTP. The RNA probes from the control and treatment groups labelled with two different colours were hybridised with one Chicken Gene Expression Microarray (Agilent Technologies) containing 43803 elements. Then, two biological replicates were conducted with alternation of Cy3- and Cy5-labelled RNA to prevent data distortion from sample labelling ${ }^{(27)}$. Microarray images were scanned, and data extraction and analysis were performed using Feature Extraction software version 10.7.3.1 (Agilent Technologies).

\section{Microarray data analysis}

GeneSpring GX10 software (Silicon Genetics) was used to qualify and normalise image analysis data and to determine the fold changes in gene expression. Average signal intensities were corrected for background signals and normalised by the locally weighted regression and smoothing scatter plots method. Flag information was applied to strain the spots with $100 \%$ valid values from each sample and an asymptotic $t$ test analysis was performed to analyse the significance between PTSO/PTS-fed and non-supplemented control groups. To generate signal ratios, signal channel values from PTSO/PTS-fed birds were divided by values from negative controls. Modulated elements were defined as RNA with $>2 \cdot 0$-fold increased or decreased levels with $P<0.05$, as determined by the Student's $t$ test. The differentially expressed genes were filtered using the Volcano Plot method $^{(28)}$ built by the $t$ test. All microarray information and data were deposited in the Gene Expression Omnibus database (series record no. GSE36302).

\section{Quantitative RT-PCR}

Gene expression changes observed by microarray analysis were confirmed by quantitative RT-PCR as described ${ }^{(29)}$. Equivalent amounts of the same RNA samples used for microarray hybridisations were reverse-transcribed using the StrataScript First Strand Synthesis System (Stratagene). Oligonucleotide primers are listed in Table 1. Amplification 
and detection were carried out using the Mx3000P system and Brilliant SYBR Green quantitative RT-PCR master mix (SABioscience, Stratagene). Standard curves were generated using $\log _{10}$ diluted standard RNA and the levels of individual transcripts were normalised to those of glyceraldehyde3-phosphate dehydrogenase (GAPDH) by the Q-gene program $^{(30)}$. For the calculation of fold changes between treatment groups, the cycle threshold $\left(C_{\mathrm{t}}\right)$ value of the target gene was normalised to GAPDH and calibrated to the relevant control value. Each analysis was performed in triplicate.

\section{Bioinformatics data analysis}

Differentially expressed genes between the PTSO/PTS-fed and control chickens were analysed using Ingenuity Pathway Analysis software (IPA) (Ingenuity Systems). Each identifier was mapped to its corresponding gene in IPA (Ingenuity Systems). Both 2.0-fold increased and 2.0-fold decreased identifiers were defined as value parameters for the analysis. These genes, termed 'focus genes', were superimposed onto the global molecular networks contained within IPA (Ingenuity Systems). Functional gene analysis was performed to identify the biological functions and canonical pathways of genes from the mapped data sets. The Fisher's exact test was used to calculate $P$ values to assess the probability of each biological function and pathway assigned to that data set. The pathways of focus genes were algorithmically generated based on their connectivity.

\section{Statistical analysis}

Data from parasite cytotoxicity assays, body weight gains, oocyst shedding, spleen lymphoproliferation and profilin antibody levels were expressed as the mean and standard deviation values. Comparisons of the mean values were performed by one-way ANOVA followed by Duncan's multiple-range test or Student's $t$ test using SPSS software (SPSS 15.0 for Windows); differences between groups were considered statistically significant at $P<0.05$.

\section{Results}

Effect of dietary propyl thiosulphinate oxide/propyl thiosulphinate on in vitro sporozoite viability and spleen cell proliferation

Treatment of freshly prepared E. acervulina sporozoites with $10 \mu \mathrm{g} / \mathrm{ml}$ of PTSO/PTS for 2 or $4 \mathrm{~h}$ significantly decreased parasite viability by 18 and $71 \%$, respectively (Fig. 1A). The reduced sporozoite viability was comparable with that produced by $5.0 \mu \mathrm{g} / \mathrm{ml}$ of chicken purified recombinant NK lysin, previously shown to be cytotoxic for E. acervulina and E. maxima parasites ${ }^{(22)}$.

PTSO/PTS significantly increased splenocyte proliferation at $2.5 \mu \mathrm{g} / \mathrm{ml}$ or higher concentrations tested compared with the medium control at $P<0 \cdot 001$ (Fig. 1B).
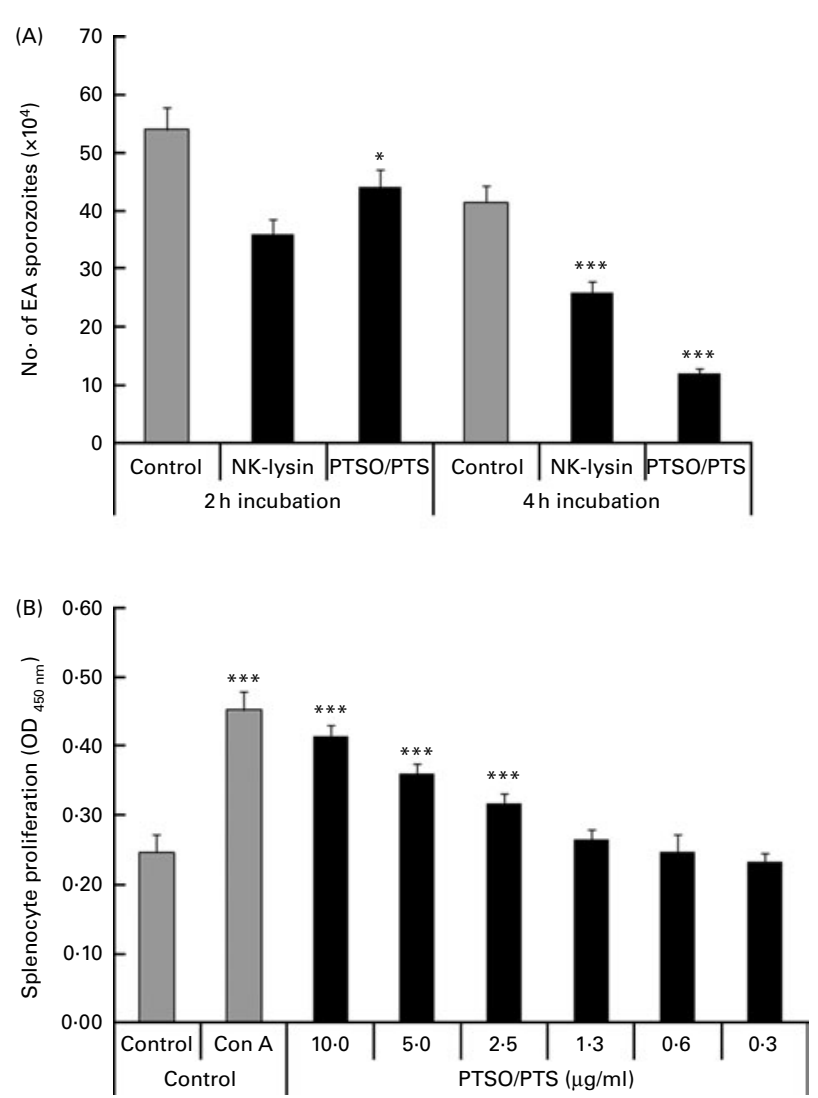

Fig. 1. Effect of propyl thiosulphinate oxide/propyl thiosulphinate (PTSO/PTS) in vitro. (A) Eimeria acervulina (EA) sporozoites $\left(1.0 \times 10^{6} / \mathrm{ml}\right)$ were incubated with PBS (control), $10 \mu \mathrm{g} / \mathrm{ml}$ of PTSO/PTS or $5.0 \mu \mathrm{g} / \mathrm{ml}$ of chicken recombinant natural killer (NK) lysin, for 2 or $4 \mathrm{~h}$ at $4^{\circ} \mathrm{C}$, and viability was measured by trypan blue exclusion by counting a minimum of 100 sporozoites. (B) Spleen cells were treated with the indicated concentrations of PTSO/PTS, concanavalin A (Con A; $5 \mu \mathrm{g} / \mathrm{ml}$ ) or medium (control) for $48 \mathrm{~h}$ and viable cell numbers were measured using 2-(2-methoxy-4-nitrophenyl)-3(4-nitrophenyl)-5-(2,4-disulphophenyl)-2H-tetrazolium. Values are means, with standard deviations represented by vertical bars $(n 3)$. Mean values were significantly different from those of PTSO/PTS-treated with control groups according to the Student's $t$ test: ${ }^{*} P<0.05 ;{ }^{* \star} P<0.001$. OD, optical density.

\section{Effect of dietary propyl thiosulphinate oxide/propyl thiosulphinate on body weight gain and faecal oocyst excretion following experimental Eimeria acervulina infection}

Dietary supplementation with PTSO/PTS significantly increased body weight gain in E. acervulina-infected chickens compared with infected birds given a non-supplemented control diet (Fig. 2A). In addition, chickens fed a diet supplemented with PTSO/PTS showed decreased faecal oocyst excretion compared with non-supplemented controls (Fig. 2B).

\section{Effect of dietary propyl thiosulphinate oxide/propyl thiosulphinate on serum anti-profilin antibody levels}

Serum antibody levels against E. acervulina profilin were measured as a parameter of humoral immunity in PTSO/PTSsupplemented and non-supplemented chickens. The profilin antibody levels were higher in Eimeria-infected chickens than 

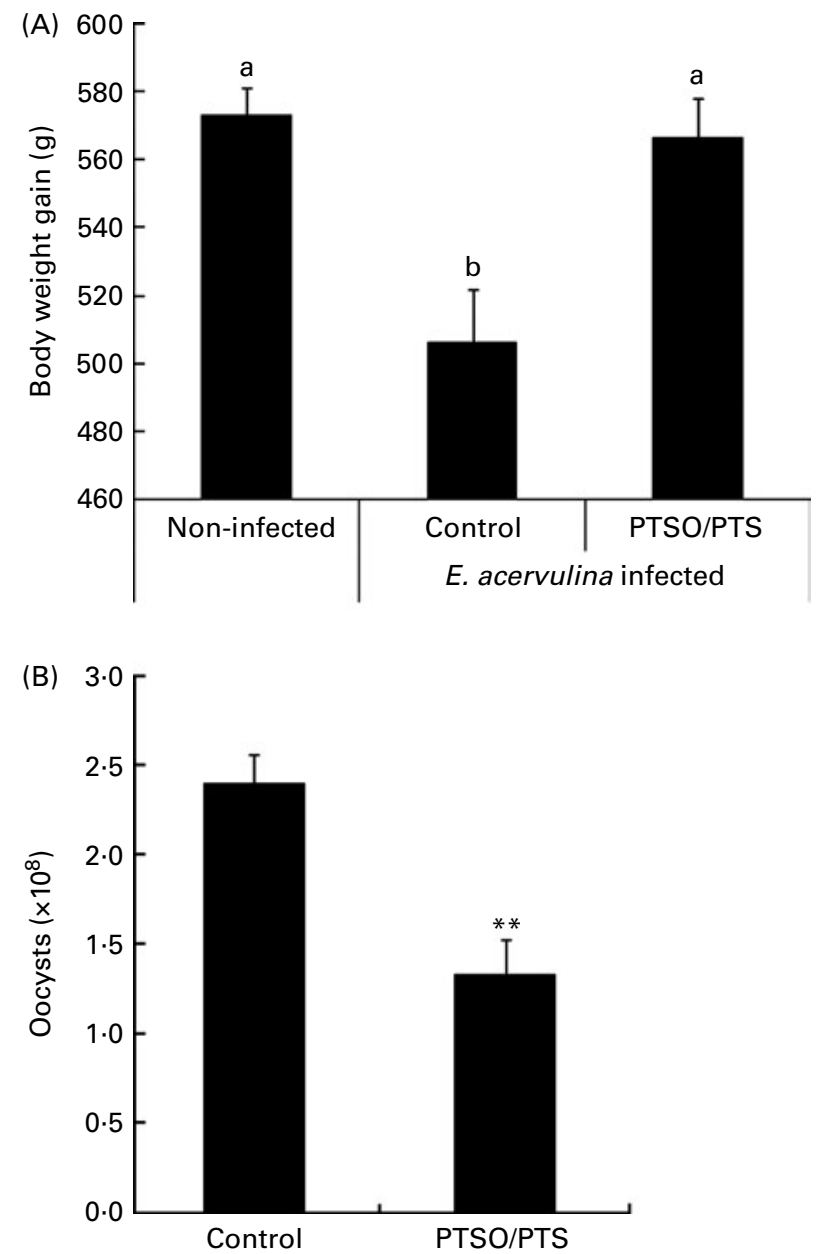

Fig. 2. Effect of dietary propyl thiosulphinate oxide/propyl thiosulphinate (PTSO/PTS) on body weight gain and faecal oocyst excretion following experimental Eimeria acervulina infection. Chickens were fed from hatch with non-supplemented or PTSO/PTS-supplemented diets and either uninfected or orally infected with $1.0 \times 10^{4}$ oocysts of E. acervulina at $10 \mathrm{~d}$ post-hatch. (A) Body weights (twenty birds/group) were measured in non-infected and infected chickens on the non-supplemented diet (control), and in infected chickens on the PTSO/PTS-supplemented diet at 0 and $10 \mathrm{~d}$ post-infection. Values are means, with standard deviations represented by vertical bars. $\mathrm{a}, \mathrm{b}$ Mean values with unlike letters were significantly different according to Duncan's multiple-range test $(P<0 \cdot 05)$. (B) Faecal samples (twenty birds/group) were collected from chickens on the non-supplemented (control) and PTSO/PTS-supplemented diets between 6 and $9 \mathrm{~d}$ post-infection and total oocyst numbers were determined using a McMaster chamber. Values are means, with standard deviations represented by vertical bars. "Mean value was significantly different from that of the control group $(P<0.01$; Students $t$ test).

in the uninfected control at $10 \mathrm{~d}$ post-infection, and dietary PTSO/PTS significantly $(P<0 \cdot 05)$ increased serum profilin antibody levels (Fig. 3) compared with non-supplemented controls.

\section{Effect of dietary propyl thiosulphinate oxide/propyl thiosulphinate on differential gene expression}

Microarray hybridisation analysis using Agilent Technologies' Chicken Gene Expression Microarray which contains 43803 elements identified 1227 mRNA whose levels were altered $>2 \cdot 0$-fold in intestinal IEL of PTSO/PTS-treated chickens compared with non-supplemented controls. Of these, 552 were

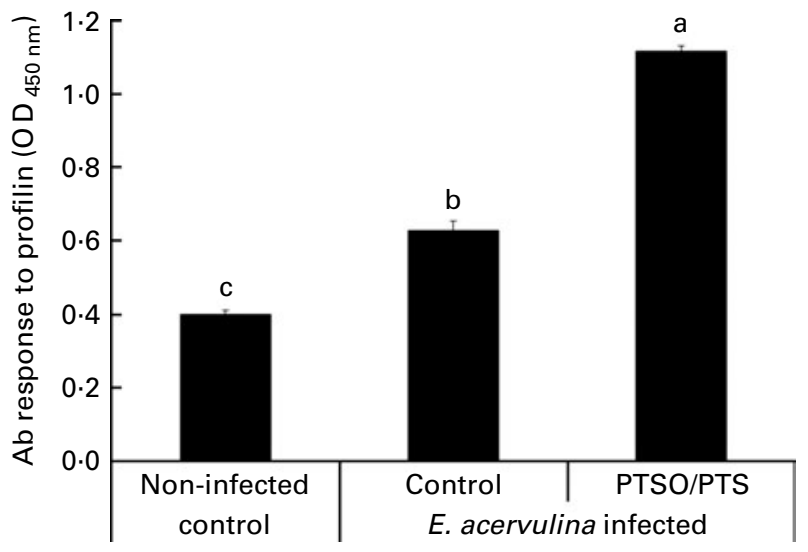

Fig. 3. Effect of dietary propyl thiosulphinate oxide/propyl thiosulphinate (PTSO/PTS) on profilin antibody (Ab) levels. Chickens were fed from hatch with non-supplemented (control) or PTSO/PTS-supplemented diets and orally infected with $1.0 \times 10^{4}$ oocysts of Eimeria acervulina at $10 \mathrm{~d}$ posthatch. Peripheral blood (four birds/group) was collected at $10 \mathrm{~d}$ post-infection and sera were analysed for anti-profilin Ab levels by ELISA. Values are means, with standard deviations represented by vertical bars $(n 4) .^{\text {a,b,c }}$ Mean values with unlike letters are significantly different according to Duncan's multiple-range test $(P<0.05)$. OD, optical density.

increased and 675 were decreased. This data set was mapped to the corresponding genes of the human, mouse and rat genome using Ingenuity Knowledge Base software (Ingenuity Systems), and 288 chicken genes were identified and annotated. Tables 2 and 3 list the genes corresponding to the twenty most up- or down-regulated transcripts, respectively.

\section{Quantitative RT-PCR validation}

The expression patterns observed by microarray analysis were validated by quantitative RT-PCR with four selected transcripts whose levels were significantly modulated between PTSO/ PTS-fed and non-treated chickens. These genes were adiponectin receptor 2 , aspartate $\beta$-hydroxylase, IL-8 and TNF (ligand) superfamily member $13 \mathrm{~b}$ (TNFSF13B). The levels of these transcripts that were up- or down-regulated by microarray hybridisation were also correspondingly altered when analysed by quantitative RT-PCR (Fig. 4). As previously discussed, the differences in the magnitude between the changes observed, particularly with adiponectin receptor 2 and aspartate $\beta$-hydroxylase, might be due to differences in the normalisation methods and/or the different fluorescent dyes used in the two techniques ${ }^{(31)}$.

\section{Biological function and pathway analyses}

Biological function analysis using the IPA (Ingenuity Systems) database was performed for the 288 genes corresponding to the mRNA that were differently altered following dietary PTSO/PTS treatment compared with untreated controls. The $P$ value associated with a particular function in this analysis is a statistical measure of the likelihood that genes from the data set under investigation participate in that function. In this manner, these genes were classified under the categories 'Disease and Disorders' and 'Physiological System Development 
Table 2. Genes corresponding to up-regulated intestinal intraepithelial lymphocyte transcripts in chickens given a propyl thiosulphinate oxide/propyl thiosulphinate-supplemented diet compared with a non-supplemented diet

\begin{tabular}{|c|c|c|c|c|c|}
\hline Symbol & Entrez gene name & Agilent no. & Fold change & Location & Function \\
\hline$P D P R$ & Pyruvate dehydrogenase phosphatase regulatory subunit & A_87_P008075 & 69.47 & Unknown & Enzyme \\
\hline ITGB1BP2 & Integrin beta 1 binding protein (melusin) 2 & A_87_P024694 & $46 \cdot 814$ & Unknown & Other \\
\hline SH3BP4 & $\mathrm{SH} 3$-domain binding protein 4 & A_87_P007874 & 38.585 & Unknown & Other \\
\hline $\mathrm{CRH}$ & Corticotropin-releasing hormone & A_87_P037220 & 32.849 & Extracellular space & Other \\
\hline SDK2 & Sidekick homologue 2 (chicken) & A_87_P037566 & 23.605 & Unknown & Other \\
\hline MDK & Midkine (neurite growth-promoting factor 2) & A_87_P009319 & $23 \cdot 142$ & Extracellular space & Growth factor \\
\hline C6ORF167 & Chromosome 6 open reading frame 167 & A_87_P037304 & 21.443 & Unknown & Other \\
\hline TMEM213 & Transmembrane protein 213 & A_87_P021765 & 20.831 & Unknown & Other \\
\hline C9ORF24 & Chromosome 9 open reading frame 24 & A_87_P020203 & $17 \cdot 712$ & Unknown & Other \\
\hline HBE1 & $\mathrm{Hb}$, epsilon 1 & A_87_P032051 & $16 \cdot 162$ & Cytoplasm & Transporter \\
\hline TRRAP & Transformation/transcription domain-associated protein & A_87_P000649 & 14.944 & Nucleus & Transcription regulator \\
\hline CBX6-NPTXR & Cbx6-Nptxr readthrough transcripts & A_87_P040723 & 12.795 & Unknown & Other \\
\hline MACF1 & Microtubule-actin crosslinking factor 1 & A_87_P011329 & 12.455 & Cytoplasm & Other \\
\hline AGXT2L1 & Ala-glyoxylate aminotransferase 2 -like 1 & A_87_P016602 & $12 \cdot 318$ & Unknown & Enzyme \\
\hline$C D O N$ & Cdon homologue (mouse) & A_87_P015827 & 11.982 & Plasma membrane & Other \\
\hline VAX1 & Ventral anterior homeobox 1 & A_87_P038172 & 11.949 & Nucleus & Transcription regulator \\
\hline VTN & Vitronectin & A_87_P008745 & 11.378 & Extracellular space & Other \\
\hline$A R C$ & Activity-regulated cytoskeleton-associated protein & A_87_P037475 & 11.005 & Cytoplasm & Other \\
\hline POMC & Pro-opiomelanocortin & A_87_P009245 & $10 \cdot 626$ & Extracellular space & Other \\
\hline
\end{tabular}

Table 3. Genes corresponding to down-regulated intestinal intraepithelial lymphocyte transcripts in chickens given a propyl thiosulphinate oxide/propyl thiosulphinate-supplemented diet compared with a non-supplemented die

\begin{tabular}{|c|c|c|c|c|c|}
\hline Symbol & Entrez gene name & Agilent no. & Fold change & Location & Function \\
\hline UCP3 & Uncoupling protein 3 (mitochondrial, proton carrier) & A_87_P037720 & 0.063 & Cytoplasm & Transporter \\
\hline F2RL2 & Coagulation factor II (thrombin) receptor-like 2 & A_87_P021894 & 0.088 & Plasma membrane & G-protein coupled receptor \\
\hline FCN2 & Ficolin (collagen/fibrinogen domain containing lectin) 2 (hucolin) & A_87_P012535 & 0.102 & Extracellular space & Other \\
\hline LAMB2 & Laminin, beta 2 (laminin S) & A_87_P037980 & 0.127 & Extracellular space & Enzyme \\
\hline C1ORF63 & Chromosome 1 open reading frame 63 & A_87_P023430 & 0.143 & Unknown & Other \\
\hline NUF2 & NUF2, NDC80 kinetochore complex component, homologue (S. cerevisiae) & A_87_P036083 & 0.154 & Nucleus & Other \\
\hline FREM1 & FRAS1 related extracellular matrix 1 & A_87_P029906 & 0.154 & Extracellular space & Other \\
\hline C5ORF34 & Chromosome 5 open reading frame 34 & A_87_P016635 & 0.165 & Unknown & Other \\
\hline TLR5 & Toll-like receptor 5 & A_87_P018174 & $0 \cdot 171$ & Plasma membrane & Transmembrane receptor \\
\hline HMGCS2 & 3-Hydroxy-3-methylglutaryl-CoA synthase 2 (mitochondrial) & A_87_P031965 & 0.171 & Cytoplasm & Enzyme \\
\hline MTMR7 & Myotubularin related protein 7 & A_87_P011372 & 0.176 & Cytoplasm & Phosphatase \\
\hline$P D C D 2 L$ & Programmed cell death 2 -like & A_87_P036130 & 0.190 & Unknown & Other \\
\hline C21ORF7 & Chromosome 21 open reading frame 7 & A_87_P023657 & 0.191 & Unknown & Other \\
\hline$S C N 2 A$ & Sodium channel, voltage-gated, type II, $\alpha$ subunit & A_87_P015799 & 0.194 & Plasma membrane & Ion channel \\
\hline C8ORF4 & Chromosome 8 open reading frame 4 & A_87_P024345 & 0.196 & Unknown & Other \\
\hline C13ORF27 & Chromosome 13 open reading frame 27 & A_87_P021548 & 0.203 & Unknown & Other \\
\hline WDR47 & WD repeat domain 47 & A_87_P034462 & 0.203 & Unknown & Other \\
\hline ER/1 & Exoribonuclease 1 & A_87_P036756 & 0.203 & Unknown & Enzyme \\
\hline PNLIP & Pancreatic lipase & A_87_P023861 & 0.211 & Extracellular space & Enzyme \\
\hline CREBL2 & cAMP responsive element binding protein-like 2 & A_87_P021605 & 0.212 & Nucleus & Transcription regulator \\
\hline
\end{tabular}




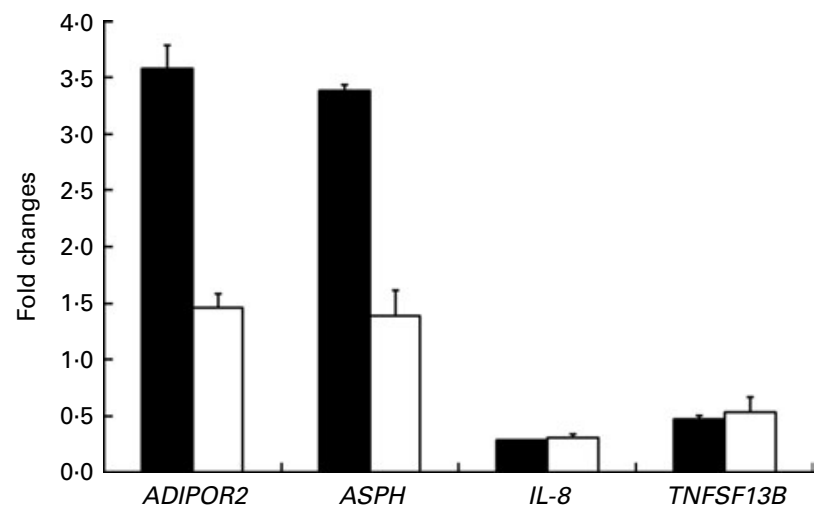

Fig. 4. Comparison between microarray ( $\square$ ) analysis and quantitative RT-PCR $(\square)$ for the levels of mRNA corresponding to selected genes. Each bar represents fold changes of mRNA levels in propyl thiosulphinate oxide/ propyl thiosulphinate-fed chickens compared with non-supplemented controls. ADIPOR2, adiponectin receptor 2; $A S P H$, aspartate $\beta$-hydroxylase; TNFSF13B, TNF (ligand) superfamily, member 13b.

and Function'. In the category 'Disease and Disorders', the most significant function that was identified was 'Inflammatory Response' (Table 4). In the category 'Physiological System Development and Function', the most significant function that was identified was 'Cardiovascular System Development and Function' (Table 5). Canonical Pathway analysis classified the genes whose expressions were significantly modified by PTSO/PTS dietary supplementation to eight selected biological functions (Table 6). Of these, the pathway of 'Communication Between Innate and Adaptive Immune Cells' was identified as the most significant pathway and included five genes. Overall, seventeen groups of pathway networks, classified according to the number of focus genes, are listed in Table 7. Fig. 5 illustrates the most significant network converging on the NF- $\mathrm{B}$ transcription factor with twenty-four focus genes identified.

\section{Discussion}

The present study was conducted to investigate the immunologic and genomic alterations following dietary supplementation with PTSO/PTS, the secondary metabolites of garlic, during E. acervulina infection of chickens.

PTSO/PTS enhanced the in vitro and in vivo parameters of immunity. Treatment of chicken spleen cells with PTSO/PTS increased their proliferation and treatment of E. acervulina sporozoites with PTSO/PTS decreased cell viability. Chickens given a PTSO/PTS-supplemented diet and infected with E. acervulina had greater body weight gain, reduced faecal oocyst excretion and increased profilin antibody responses compared with chickens fed a non-supplemented diet. Some of these responses may have been due to a direct cytotoxic effect of PTSO/PTS on parasite sporozoites. Microarray hybridisation identified 1227 transcripts whose levels were significantly altered in the intestinal IEL of PTSO/PTS-fed birds compared with non-supplemented controls. Biological pathway analysis identified the altered transcripts as belonging to the categories 'Disease and Disorder' and 'Physiological System Development and Function'.
Garlic has been traditionally used as a folk remedy to treat a variety of human diseases, the health-promoting effects of which are attributed to the presence of multiple sulphurcontaining compounds, such as diallyl sulphide, diallyl disulphide, dipropyl sulphide and allicin. These compounds, and others, have demonstrated pharmacological activity in vitro and in vivo ${ }^{(32-35)}$. Allicin is generally considered to be one of the primary active compounds that gives garlic its characteristic odour and many of its healing benefits. Thiacremonone, a novel sulphur compound isolated from garlic, possesses anti-inflammatory properties through the inhibition of NF-кB activation in rats and mice ${ }^{(36)}$. NF- $\mathrm{kB}$ is a major transcription factor that plays a key role in regulating the immune response to infection following the binding of pathogenic microorganisms to a variety of cell surface receptors, such as Tolllike receptors $(\mathrm{TLR})^{(37)}$. Our bioinformatic analysis identified $\mathrm{NF}-\kappa \mathrm{B}$ as a central molecule in the most significant network that was activated in PTSO/PTS-treated chickens. This network also included TLR3 and TLR5 as down-regulated components. Further evidence for the modulation of TLR and $\mathrm{NF}-\kappa \mathrm{B}$ in response to garlic comes from the study of Youn et $a l .{ }^{(38)}$ showing that the ethyl acetate fraction of the plant bulb inhibited lipopolysaccharide-induced dimerisation of TLR4 and blocked NF-кB activation.

Interestingly, however, our functional studies indicated that dietary PTSO/PTS increased the resistance of chickens to experimental E. acervulina infection, as evidenced by greater weight gain and reduced parasite excretion, and augmented parameters of adaptive immunity, including a higher profilin antibody response and greater spleen cell proliferation, compared with chickens fed a non-supplemented diet. The ability of PTSO/PTS to directly kill sporozoites and stimulate spleen cell proliferation in vitro suggests that a similar mechanism may operate in vivo, thus contributing to increased body weight and decreased parasite fecundity.

The capability of the PTSO/PTS preparation to stimulate spleen cell mitogenesis (an indicator of adaptive cellular immunity), while simultaneously down-regulating TLR and NF- $\mathrm{KB}$ (indicators of innate immunity), suggests that the dietary supplement may have more than one active component. In this regard, Clement et al. ${ }^{(39)}$ identified several immunomodulatory proteins from garlic with mitogenic activity towards human peripheral blood lymphocytes and murine splenocytes. Further studies to characterise the active components of garlic and their effects on innate and adaptive immunity will help to resolve these questions.

In the biological functional analysis, eighteen genes were related with the most reliable 'Inflammatory Response' category (Table 4). Among those genes, TLR are a major component of the pattern recognition receptor repertoire that detect invading micro-organisms and direct the vertebrate immune system to eliminate infection. TLR5 plays a role in restricting the entry of flagellated Salmonella into systemic sites ${ }^{(40)}$ and TLR3 which recognises double-stranded RNA analogue, induces interferon- $\beta$ through the recognition of viral double-stranded RNA in chicken ${ }^{(41)}$. In the present study, TLR3 and TLR5 expression was down-regulated in the bioinfomatical analysis and this may explain the reduced inflammatory response 
Table 4. Significant functions in the category 'Disease and Disorders' in chickens given a propyl thiosulphinate oxide/propyl thiosulphinate-supplemented diet compared with a non-supplemented diet

\begin{tabular}{|c|c|c|}
\hline Category* $^{*}$ & $P \dagger$ & Genes \\
\hline Inflammatory response & $2.30 \times 10^{-3}-4.24 \times 10^{-2}$ & $\begin{array}{l}\text { UNC13D, IL8, VCAM1, VTN, CRH, POMC, JAK2, RNASEL, SELP, TLR5, KL, PLCG2, MDK, HPGDS, TLR3, ADIPOR2, } \\
\text { TFPI, TNFSF13B }\end{array}$ \\
\hline Dermatological diseases and conditions & $4.11 \times 10^{-3}-3.75 \times 10^{-2}$ & IL8, SELP, KL, HBEGF, TNFRSF8, DSP \\
\hline Endocrine system disorders & $4.11 \times 10^{-3}-4.11 \times 10^{-3}$ & UBR1, CCKBR \\
\hline Inflammatory disease & $4.11 \times 10^{-3}-3.75 \times 10^{-2}$ & IL8, VCAM1, SELP, TLR5, ICA1, PDE5A, HBEGF, TLR3, TNFRSF8, TNPO3, TNFSF13B \\
\hline Organismal injury and abnormalities & $4.11 \times 10^{-3}-4.75 \times 10^{-2}$ & SOCS3, IL8, F2RL2, SELP, VTN, UBR1, CRH, PDE5A, HBEGF, MDK, HPGDS, CCKBR \\
\hline Renal and urological disease & $4.11 \times 10^{-3}-3.75 \times 10^{-2}$ & VCAM1, SELP, PDE5A, HBEGF, TLR3, MDK, TNFSF13B, ZNF365 \\
\hline Genetic disorder & $8.01 \times 10^{-3}-3.75 \times 10^{-2}$ & $\begin{array}{l}\text { SLC4A4, HCRT, SGCE, DNAJC19, CACNB4, CRH, CACNA1H, POMC, JAK2, HMGCS2, CEP290, MAOB, TLR5, LGI1, } \\
\quad \text { ATCAY, DSP, ATN1, ZNF365 }\end{array}$ \\
\hline Infection mechanism & $8.01 \times 10^{-3}-4.24 \times 10^{-2}$ & IL8, TLR5, PLCG2, CD93, TLR3 \\
\hline Infectious disease & $8.01 \times 10^{-3}-4.24 \times 10^{-2}$ & IL8, TLR5, PLCG2, CD93, TLR3 \\
\hline Metabolic disease & $8.01 \times 10^{-3}-4.91 \times 10^{-2}$ & SOCS3, PLIN1, ICA1, DNAJC19, CRH, HBEGF, POMC, HMGCS2, LAMB2, SCP2, TLR3, ADIPOR2, CCKBR, ZNF365 \\
\hline Neurological disease & $8.01 \times 10^{-3}-3.75 \times 10^{-2}$ & CA3, SCN2A, MAOB, HCRT, SGCE, ABCC5, LGI1, CACNB4, CACNA1H, ATCAY, HPGDS, ATN1 \\
\hline Nutritional disease & $1.14 \times 10^{-2}-4.75 \times 10^{-2}$ & UCP3, HCRT, POMC, CCKBR \\
\hline Psychological disorders & $1.14 \times 10^{-2}-4.75 \times 10^{-2}$ & UCP3, HCRT, POMC, CCKBR \\
\hline Gastrointestinal disease & $1.14 \times 10^{-2}-4.00 \times 10^{-2}$ & $\begin{array}{l}\text { SOCS3, CTRC, PIAS2, DNMT3A, CUBN, LRRC1, HLA-DRB1, SYNE1, TUFT1, KLHL20, NSF, CA3, KIF9, KCTD20, LNPEP, } \\
\text { UBXN4, EFNA5, HPGD, TNFSF15, RERE, ASPH, TLR3, FABP3, CCKBR, IL8, JAZF1, ICA1, SEC16A, MEF2A, MYPN, } \\
\text { TPD52, ITPR1, NFASC, REV3L, FREM1, SH3BP5, HOPX, SELP, EDEM2, TLR5, SCP2, REEP3, PDE5A, TRANK1, } \\
\text { ZNF365 }\end{array}$ \\
\hline Hepatic system disease & $1.14 \times 10^{-2}-3.75 \times 10^{-2}$ & JAZF1, CUBN, EFNA5, TUFT1, MYPN, ITPR1, REV3L, TLR3 \\
\hline Connective tissue disorders & $1.15 \times 10^{-2}-2.60 \times 10^{-2}$ & VCAM1, PLIN1, SELP, TLR5, ICA1, TNPO3, TNFSF13B, CCKBR \\
\hline Immunological disease & $1.15 \times 10^{-2}-1.15 \times 10^{-2}$ & VCAM1, SELP, TLR5, ICA1, TNPO3, TNFSF13B \\
\hline Skeletal and muscular disorders & $1.15 \times 10^{-2}-3.75 \times 10^{-2}$ & VCAM1, SELP, TLR5, ICA1, MEF2A, TNPO3, TNFSF13B \\
\hline CVD & $1.30 \times 10^{-2}-3.75 \times 10^{-2}$ & F2RL2, VCAM1, VTN, TFPI, DSP \\
\hline Haematological disease & $1.30 \times 10^{-2}-4.75 \times 10^{-2}$ & SOCS3, IL8, F2RL2, SELP, SCP2, POMC, JAK2, TFPI \\
\hline Antimicrobial response & $2.60 \times 10^{-2}-3.75 \times 10^{-2}$ & NCOR1, TLR3, RNASEL \\
\hline Developmental disorder & $2.60 \times 10^{-2}-3.75 \times 10^{-2}$ & CEP290, PLIN1, REV3L, ASPH, TLR3, DSP, CCKBR \\
\hline Cancer & $3.38 \times 10^{-2}-3.75 \times 10^{-2}$ & $D D X 5, L M O 4, K L, H B E G F, J A K 2, A S P H$ \\
\hline Hypersensitivity response & $3.38 \times 10^{-2}-4.24 \times 10^{-2}$ & IL8, VCAM1, SELP, TLR3 \\
\hline Respiratory disease & $3.75 \times 10^{-2}-3.75 \times 10^{-2}$ & TLR5, PDE5A \\
\hline
\end{tabular}

* Data sets were analysed by BioFunction analysis using Ingenuity Pathway Analysis software (Ingenuity Systems).

$\dagger P$-value ranges of the biological functions included in the category. $P$ values were calculated using the right-tailed Fisher's exact test. 
Table 5. Significant functions in the category 'Physiological System Development and Function' in chickens given a propyl thiosulphinate oxide/propyl thiosulphinate-supplemented diet compared with a non-supplemented diet

\begin{tabular}{|c|c|c|}
\hline Category ${ }^{*}$ & $P \dagger$ & Genes \\
\hline $\begin{array}{l}\text { Cardiovascular system development and } \\
\text { function }\end{array}$ & $1.21 \times 10^{-4}-4.86 \times 10^{-2}$ & $\begin{array}{l}\text { IL8, VCAM1, GEM, VTN, MEF2A, ANGPTL2, CRH, POMC, DICER1, JAK2, KLHL20, MLL, SELP, TNFSF15, MDK, ASPH, } \\
\text { TFPI }\end{array}$ \\
\hline $\begin{array}{l}\text { Nervous system development and } \\
\text { function }\end{array}$ & $9.61 \times 10^{-4}-4.22 \times 10^{-2}$ & $\begin{array}{l}\text { F2RL2, VAX1, VCAM1, HCRT, GEM, LMO4, CACNA1H, CRH, DLX1, POMC, JAK2, BCL11B, LAMB2, SELP, EFNA5, } \\
\text { CDON, HPGDS, TLR3 }\end{array}$ \\
\hline Embryonic development & $1.40 \times 10^{-3}-3.75 \times 10^{-2}$ & SOCS3, VAX1, VCAM1, CTCF, GDF3, KL, MYST3, SEMA6D, HBEGF, GREM1, TRRAP, MLL \\
\hline Behaviour & $1.64 \times 10^{-3}-4.24 \times 10^{-2}$ & HCRT, SLC16A2, CRH, POMC \\
\hline $\begin{array}{l}\text { Haematological system development and } \\
\text { function }\end{array}$ & $1.99 \times 10^{-3}-4.75 \times 10^{-2}$ & $\begin{array}{l}\text { IL8, SOCS3, VCAM1, VTN, CDK6, CRH, HLA-DRB1, POMC, JAK2, MLL, KCNK5, TLR5, SELP, MYST3, TNFSF15, } \\
\text { TNFRSF8, TLR3, WASF2, MDK, TNFSF13B }\end{array}$ \\
\hline Haematopoiesis & $1.99 \times 10^{-3}-4.44 \times 10^{-2}$ & SOCS3, IL8, VCAM1, SELP, MYST3, CDK6, CRH, POMC, JAK2, MLL, TNFSF13B \\
\hline Organismal development & $1.99 \times 10^{-3}-4.94 \times 10^{-2}$ & $\begin{array}{l}\text { SOCS3, IL8, VCAM1, PLIN1, GDF3, CDK6, CRH, UBR1, POMC, JAK2, MLL, KLHL20, LAMB2, KCNK5, UCP3, MAOB, } \\
\text { SELP, MYST3, TLR3 }\end{array}$ \\
\hline Immune cell trafficking & $2.30 \times 10^{-3}-4.44 \times 10^{-2}$ & IL8, VCAM1, TLR5, SELP, VTN, CRH, POMC, TLR3, MDK, JAK2, TNFSF13B \\
\hline Tissue development & $2.30 \times 10^{-3}-4.75 \times 10^{-2}$ & $\begin{array}{l}\text { IL8, SOCS3, VAX1, VCAM1, GDF3, VTN, UBR1, GREM1, POMC, NFASC, JAK2, SELP, KL, TLR3, TFPI, PRKD1, } \\
\text { TNFSF13B }\end{array}$ \\
\hline $\begin{array}{l}\text { Connective tissue development and } \\
\text { function }\end{array}$ & $4.11 \times 10^{-3}-3.75 \times 10^{-2}$ & VCAM1, UCP3, PLIN1, KL, UBR1, CRH, POMC \\
\hline Tissue morphology & $4.11 \times 10^{-3}-4.75 \times 10^{-2}$ & SOCS3, VCAM1, PLIN1, LMO4, VTN, CRH, UBR1, POMC, UCP3, SELP, KL, TNFSF13B, CCKBR \\
\hline Cell-mediated immune response & $6.90 \times 10^{-3}-3.75 \times 10^{-2}$ & SOCS3, IL8, VCAM1, SELP, TNFSF13B \\
\hline $\begin{array}{l}\text { Endocrine system development and } \\
\text { function }\end{array}$ & $8.01 \times 10^{-3}-4.24 \times 10^{-2}$ & $D B I, C O M T, C R H, P O M C, C C K B R$ \\
\hline Organ morphology & $8.01 \times 10^{-3}-3.75 \times 10^{-2}$ & VCAM1, SELP, MEF2A (includes EG:4205), CRH, HBEGF, POMC, DICER1, TNFSF13B, CCKBR \\
\hline Organismal functions & $8.01 \times 10^{-3}-3.75 \times 10^{-2}$ & IL8, MAOB, HCRT, COMT, CRH \\
\hline $\begin{array}{l}\text { Skeletal and muscular system } \\
\text { development and function }\end{array}$ & $1.30 \times 10^{-2}-3.75 \times 10^{-2}$ & LAMB2, SOCS3, HOPX, PLIN1, LMO4, KL, VTN, CDON, MDK, MYOG, TFPI, BARX2 \\
\hline $\begin{array}{l}\text { Lymphoid tissue structure and } \\
\text { development }\end{array}$ & $1.32 \times 10^{-2}-3.75 \times 10^{-2}$ & IL8, SELP, VTN, MDK, TFPI, TNFSF13B \\
\hline $\begin{array}{l}\text { Reproductive system development and } \\
\text { function }\end{array}$ & $1.32 \times 10^{-2}-4.24 \times 10^{-2}$ & SOCS3, NSF, VCAM1, GNPDA1, LNPEP, COMT, CRH, HPGD, HBEGF \\
\hline $\begin{array}{l}\text { Digestive system development and } \\
\text { function }\end{array}$ & $1.91 \times 10^{-2}-3.75 \times 10^{-2}$ & $H C R T, C R H, C C K B R$ \\
\hline Organ development & $3.38 \times 10^{-2}-3.75 \times 10^{-2}$ & SOCS3, IL8, VAX1, SELP, CRH, POMC \\
\hline $\begin{array}{l}\text { Auditory and vestibular system } \\
\text { development and function }\end{array}$ & $3.75 \times 10^{-2}-3.75 \times 10^{-2}$ & IL8 \\
\hline $\begin{array}{l}\text { Hair and skin development } \\
\text { and function }\end{array}$ & $3.75 \times 10^{-2}-4.24 \times 10^{-2}$ & IL8, CTCF, ABCC5, POMC, JAK2, DSP \\
\hline Humoral immune response & $3.75 \times 10^{-2}-3.75 \times 10^{-2}$ & TNFSF13B \\
\hline Organismal survival & $3.75 \times 10^{-2}-3.75 \times 10^{-2}$ & TLR3 \\
\hline $\begin{array}{l}\text { Renal and urological system } \\
\text { development and function }\end{array}$ & $3.75 \times 10^{-2}-3.75 \times 10^{-2}$ & KCNK5, GEM, CTCF, CDK6, GREM1 \\
\hline $\begin{array}{l}\text { Respiratory system development and } \\
\text { function }\end{array}$ & $3.75 \times 10^{-2}-3.75 \times 10^{-2}$ & GREM1, DICER1 \\
\hline Tumour morphology & $3.75 \times 10^{-2}-4.75 \times 10^{-2}$ & SOCS3, VCAM1, VTN, NFASC, TFPI \\
\hline
\end{tabular}

* Data sets were analysed by BioFunction analysis using Ingenuity Pathway Analysis software (Ingenuity Systems).

$\dagger P$-value ranges of the biological functions included in the category. $P$ values were calculated using the right-tailed Fisher's exact test. 
Table 6. Significant canonical pathways in chickens given a propyl thiosulphinate oxide/propyl thiosulphinate-supplemented diet compared with a non-supplemented diet

\begin{tabular}{|c|c|c|c|}
\hline Canonical pathway* & $P \dagger$ & Ratioł & Focus genes \\
\hline Communication between innate and adaptive immune cells & $1.38 \times 10^{-3}$ & $4.67 \times 10^{-2}$ & IL-8, TLR5, HLA-DRB1, TLR3, TNFSF13B \\
\hline Corticotropin-releasing hormone signalling & $2.04 \times 10^{-3}$ & $5.88 \times 10^{-2}$ & PLCG2, GNAl1, CRH, MEF2A (includes EG:4205), POMC, ITPR1, ADCY7, PRKD1 \\
\hline TREM1 signalling & $4.07 \times 10^{-3}$ & $7.25 \times 10^{-2}$ & IL-8, TLR5, PLCG2, JAK2, TLR3 \\
\hline$\alpha$-Adrenergic signalling & $9.55 \times 10^{-3}$ & $5.66 \times 10^{-2}$ & PHKB, PLCG2, GNAI1, ITPR1, ADCY7, PRKD1 \\
\hline Altered T-cell and B-cell signalling in rheumatoid arthritis & $1.95 \times 10^{-2}$ & $4.40 \times 10^{-2}$ & TLR5, HLA-DRB1, TLR3, TNFSF13B \\
\hline Glutathione metabolism & $2.45 \times 10^{-2}$ & $4.08 \times 10^{-2}$ & GSTT1, LNPEP, ACSS2, HPGDS \\
\hline Cyanoamino acid metabolism & $2.63 \times 10^{-2}$ & $3.12 \times 10^{-2}$ & $K L$, ACSS2 \\
\hline Leptin signalling in obesity & $3.80 \times 10^{-2}$ & $5.95 \times 10^{-2}$ & SOCS3, PLCG2, POMC, JAK2, ADCY7 \\
\hline
\end{tabular}

TREM1, triggering receptor expressed on myeloid cells 1 .

* Data sets were analysed by Bio Function analysis using Ingenuity Pathway Analysis software (Ingenuity Systems).

$\dagger P$ values were calculated using the right-tailed Fisher's exact test.

The ratio of the number of genes from the data set that map to the pathway divided by the total number of genes that map to the canonical pathway.

Table 7. Significant networks in chickens given a propyl thiosulphinate oxide/propyl thiosulphinate-supplemented diet compared with a non-supplemented diet

\begin{tabular}{|c|c|c|c|}
\hline ID & Associated network functions & No. of focus genes & Score \\
\hline 1 & Cellular compromise, cell-to-cell signalling and interaction, cellular growth and proliferation & 24 & 38 \\
\hline 2 & Cardiovascular system development and function, lipid metabolism, small-molecule biochemistry & 21 & 32 \\
\hline 3 & Connective tissue development and function, embryonic development, skeletal and muscular system development and function & 19 & 29 \\
\hline 4 & Cell morphology, cellular development, cellular movement & 21 & 28 \\
\hline 5 & Cardiovascular system development and function, cell morphology, cellular development & 19 & 28 \\
\hline 6 & Carbohydrate metabolism, small-molecule biochemistry, lipid metabolism & 17 & 24 \\
\hline 7 & Endocrine system development and function, nervous system development and function, tissue morphology & 16 & 21 \\
\hline 8 & Lipid metabolism, small-molecule biochemistry, amino acid metabolism & 15 & 20 \\
\hline 9 & Free-radical scavenging, genetic disorder, metabolic disease & 14 & 19 \\
\hline 10 & Cell signalling, nucleic acid metabolism, small-molecule biochemistry & 14 & 19 \\
\hline 11 & Gene expression, cellular compromise, connective tissue disorders & 13 & 17 \\
\hline 12 & Cell cycle, cellular development, gene expression & 13 & 16 \\
\hline 13 & Organismal functions, haematological system development and function, tissue morphology & 12 & 15 \\
\hline 14 & Cardiovascular system development and function, molecular transport, small-molecule biochemistry & 12 & 15 \\
\hline 15 & DNA replication, recombination, and repair, energy production, nucleic acid metabolism & 12 & 15 \\
\hline 16 & Molecular transport, small-molecule biochemistry, cell-to-cell signalling and interaction & 12 & 15 \\
\hline 17 & Cell cycle, DNA replication, recombination, and repair, cellular growth and proliferation & 12 & 14 \\
\hline
\end{tabular}


seen at the later phase of coccidiosis infection. Although the underlying mechanisms are not yet known, it was found that garlic increases NK cell activity and $\mathrm{T}$ cell proliferation in mice ${ }^{(42)}$. Aged garlic extract treatment enhanced NK cell activity $^{(43,44)}$ and phagocytosis ${ }^{(5)}$. The balance of $\mathrm{T}$ helper $1 / \mathrm{T}$ helper 2-type cytokines, such as the secretion of interferon- $\gamma$ and IL- $2 v$. IL- 4 and IL-10, was regulated by the consumption of garlic products in a dose-dependent manner ${ }^{(45-47)}$. In chickens, IEL contains two major phenotypically and functionally distinct populations, NK and $\mathrm{T}$ cells, and these cells play important roles in avian coccidiosis ${ }^{(17)}$. Therefore, it is possible that dietary garlic enhanced disease resistance against coccidiosis by activating these effector cells and enhancing the secretion of immunomodulating cytokines in the gut. The TNF family is an important regulator of inflammation, immune responses and tissue homeostasis ${ }^{(48)}$. TNFSF13B, also known as B-cell activating factor (B-cell activating factor of the TNF family), plays a major role in B-cell survival, proliferation and differentiation. TNFSF13B induced the selective expansion of B cells in the spleen and caecal tonsils when administered to young chicks $^{(49)}$. The level of TNFSF13B was shown to increase during various diseases that may reflect the severity of disease in malaria, virus infection and multiple sclerosis ${ }^{(50-52)}$. However, the overexpression of TNFSF13B is also involved in some autoimmune conditions ${ }^{(53,54)}$. In the present study, dietary feeding of normal chickens with PTSO/PTS enhanced serum antibody response to $E$. acervulina infection in Eimeria-infected chickens when antibodies were measured at $10 \mathrm{~d}$ after infection. However, for gene expression analysis, we used uninfected gut tissues from chickens treated with PTSO/PTS, and we saw the decreased TNFSF13B transcript compared to the chickens that were not fed with PTSO/PTS. Therefore, we speculate that the expression of TNFSF13B may have increased upon coccidiosis infection and this may have caused high antibody response. Chicken IL-8 (IL-8/ CXCLi2) was the first chicken CXC chemokine identified and significantly triggered by the exposure of the gut to feed and bacteria in newly hatched chicks ${ }^{(55)}$. IL-8 has both chemotactic and angiogenic functions in the chicken ${ }^{(56)}$; so this gene was also identified in the 'Cardiovascular System Development

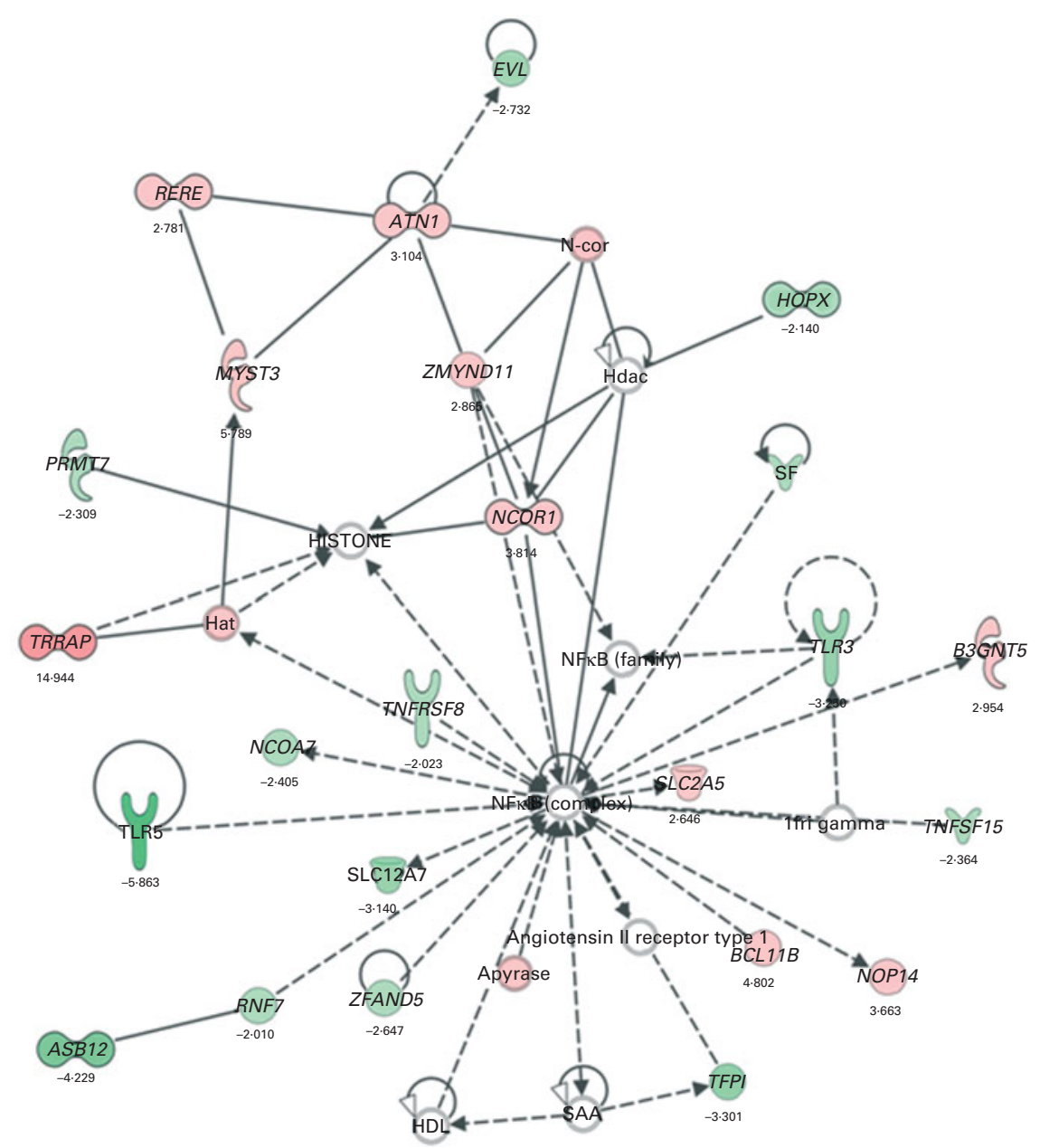

Fig. 5. The most significant network with the indicated genes corresponding to mRNA exhibiting $>2 \cdot 0$-fold up- and down-regulated levels following dietary supplementation of propyl thiosulphinate oxide/propyl thiosulphinate compared with non-supplemented controls. Genes corresponding to increased and decreased mRNA are indicated by red and green colours, respectively, with the colour intensity indicating the relative expression levels. Overlaid numbers are the fold changes associated with each gene. $\bigcirc$, Complex; $\vee$, cytokine/growth factor; \&, enzyme; 0 , group/complex/other; $\bowtie$, transcription regulator; $\vee$, transmembrane receptor; $\ominus$, transporter; $\bigcirc$, unknown; -, direct relationship; --, indirect relationship. 
and Function' category (Table 5). At low concentrations, IL-8 is chemotactic for monocyte/macrophages and lymphocytes. However, at high concentrations, IL-8 stimulates sprouting and growth of blood vessels ${ }^{(57)}$.

In addition to effects on inflammation and immunity, dietary garlic dramatically affects the cardiovascular system ${ }^{(58)}$. For example, garlic consumption by humans may diminish the progression of CVD by decreasing the levels of LDL and total cholesterol, while concomitantly raising HDL levels. Consumption of garlic is also associated with the inhibition of platelet aggregation and reduced systolic and diastolic blood pressure. Recently, garlic was found to decrease two other markers of CVD, homocysteine and C-reactive protein. Interestingly, our present results identified 'Cardiovascular System Development and Function' as the most significant function in the category 'Physiological System Development and Function' of PTSO/PTS-fed chickens. This finding may extend the effects of garlic metabolites to poultry. However, the underlying pathways associated with the cardiovascular system in poultry still needs to be studied.

In conclusion, in vivo feeding of young broiler chickens with PTSO/PTS compound, a garlic-derived extract, improved resistance to experimental E. acervulina infection and induced significant alterations of the transcriptome in chicken intestinal lymphocytes involving immune- and cardiovascular-related gene pathways and networks. These results suggest that dietary immunomodulation by garlic-derived compounds may represent a possible alternative to current drug-based strategies for commercial poultry production.

\section{Acknowledgements}

The authors state that there are no conflicts of interest. D. K. K. conceived and performed the experiments, analysed the data and wrote the manuscript; H. S. L. conceived and designed the experiments; S. H. L. designed and performed the experiments; E. P. L. contributed to write the manuscript; D. B. conceived the experiments. The authors thank Marjorie Nichols and Stacy Torreyson for their technical assistance. This project was supported by a Trust agreement between Agricultural Research Service-United States Department of Agriculture and Pancosma.

\section{References}

1. Imai J, Ide N, Nagae S, et al. (1994) Antioxidant and radical scavenging effects of aged garlic extract and its constituents. Planta Med 60, 417-420.

2. Rivlin RS (2001) Historical perspective on the use of garlic. J Nutr 131, 951S-954S.

3. O'Gara EA, Hill DJ \& Maslin DJ (2000) Activities of garlic oil, garlic powder, and their diallyl constituents against Helicobacter pylori. Appl Environ Microbiol 66, 2269-2273.

4. Tsao SM \& Yin MC (2001) In-vitro antimicrobial activity of four diallyl sulphides occurring naturally in garlic and Chinese leek oils. J Med Microbiol 50, 646-649.

5. Kyo E, Uda N, Kasuga S, et al. (2001) Immunomodulatory effects of aged garlic extract. J Nutr 131, 1075S-1079S
6. Choi IH, Park WY \& Kim YJ (2010) Effects of dietary garlic powder and \{alpha\}-tocopherol supplementation on performance, serum cholesterol levels, and meat quality of chicken. Poult Sci 89, 1724-1731.

7. Hanieh H, Narabara K, Piao M, et al. (2010) Modulatory effects of two levels of dietary Alliums on immune response and certain immunological variables, following immunization, in White Leghorn chickens. Anim Sci J 81, 673-680.

8. Chowdhury SR, Chowdhury SD \& Smith TK (2002) Effects of dietary garlic on cholesterol metabolism in laying hens Poult Sci 81, 1856-1862.

9. Kim JS \& Kim Y (2007) The inhibitory effect of natural bioactives on the growth of pathogenic bacteria. Nutr Res Pract 1, 273-278.

10. Iciek M, Kwiecien I \& Wlodek L (2009) Biological properties of garlic and garlic-derived organosulfur compounds. Environ Mol Mutagen 50, 247-265.

11. Ayaz E, Turel I, Gul A, et al. (2008) Evaluation of the anthelmentic activity of garlic (Allium sativum) in mice naturally infected with Aspiculuris tetraptera. Recent Pat Antiinfect Drug Discov 3, 149-152.

12. Abdel-Ghaffar F, Semmler M, Al-Rasheid KA, et al. (2011) The effects of different plant extracts on intestinal cestodes and on trematodes. Parasitol Res 108, 979-984

13. Hafez HM \& Hauck R (2006) Efficacy of a herbal product against Histomonas meleagridis after experimental infection of turkey poults. Arch Anim Nutr 60, 436-442.

14. Dkhil MA, Abdel-Baki AS, Wunderlich F, et al. (2011) Anticoccidial and antiinflammatory activity of garlic in murine Eimeria papillata infections. Vet Parasitol 175, 66-72.

15. Toulah FH \& Al-Rawi MM (2007) Efficacy of garlic extract on hepatic coccidiosis in infected rabbits (Oryctolagus cuniculus): histological and biochemical studies. J Egypt Soc Parasitol 37, 957-968.

16. Neutra MR, Mantis NJ \& Kraehenbuhl JP (2001) Collaboration of epithelial cells with organized mucosal lymphoid tissues. Nat Immunol 2, 1004-1009.

17. Gobel TW, Kaspers B \& Stangassinger M (2001) NK and $\mathrm{T}$ cells constitute two major, functionally distinct intestinal epithelial lymphocyte subsets in the chicken. Int Immunol 13, 757-762.

18. Lillehoj HS \& Trout JM (1996) Avian gut-associated lymphoid tissues and intestinal immune responses to Eimeria parasites Clin Microbiol Rev 9, 349-360.

19. Hong YH, Lillehoj HS, Lillehoj EP, et al. (2006) Changes in immune-related gene expression and intestinal lymphocyte subpopulations following Eimeria maxima infection of chickens. Vet Immunol Immunopathol 114, 259-272.

20. Lillehoj HS, Kim DK, Bravo DM, et al. (2011) Effects of dietary plant-derived phytonutrients on the genome-wide profiles and coccidiosis resistance in the broiler chickens. BMC Proc 5, Suppl. 4, S34.

21. Lillehoj HS \& Lillehoj EP (2000) Avian coccidiosis. A review of acquired intestinal immunity and vaccination strategies. Avian Dis 44, 408-425.

22. Hong YH, Lillehoj HS, Siragusa GR, et al. (2008) Antimicrobial activity of chicken NK-lysin against Eimeria sporozoites. Avian Dis 52, 302-305.

23. National Research and Council (1994) Nutrient Requirements of Poultry, Ninth Revised Edition, Subcommittee on Poultry Nutrition Committee on Animal Nutrition, Board on Agriculture. Washington, DC: National Academy Press.

24. Lee SH, Lillehoj HS, Park DW, et al. (2009) Protective effect of hyperimmune egg yolk IgY antibodies against Eimeria tenella and Eimeria maxima infections. Vet Parasitol 163 $123-126$ 
25. Jang SI, Lillehoj HS, Lee SH, et al. (2011) Montanide ISA 71 VG adjuvant enhances antibody and cell-mediated immune responses to profilin subunit antigen vaccination and promotes protection against Eimeria acervulina and Eimeria tenella. Exp Parasitol 127, 178-183.

26. Min W, Lillehoj HS, Ashwell CM, et al. (2005) Expressed sequence tag analysis of Eimeria-stimulated intestinal intraepithelial lymphocytes in chickens. Mol Biotechnol 30 , 143-150.

27. McShane LM, Shih JH \& Michalowska AM (2003) Statistical issues in the design and analysis of gene expression microarray studies of animal models. J Mammary Gland Biol Neoplasia 8, 359-374.

28. Jin K, Mao XO, Eshoo MW, et al. (2001) Microarray analysis of hippocampal gene expression in global cerebral ischemia. Ann Neurol 50, 93-103.

29. Hong YH, Lillehoj HS, Lee SH, et al. (2006) Molecular cloning and characterization of chicken lipopolysaccharideinduced TNF-alpha factor (LITAF). Dev Comp Immunol 30, 919-929

30. Muller PY, Janovjak H, Miserez AR, et al. (2002) Processing of gene expression data generated by quantitative real-time RT-PCR. Biotechniques 32, 1372-1374, 1376, 1378-1379.

31. Lee PD, Sladek R, Greenwood CM, et al. (2002) Control genes and variability: absence of ubiquitous reference transcripts in diverse mammalian expression studies. Genome Res 12, 292-297.

32. Murugavel P \& Pari L (2007) Effects of diallyl tetrasulfide on cadmium-induced oxidative damage in the liver of rats. Hum Exp Toxicol 26, 527-534.

33. Park EY, Ki SH, Ko MS, et al. (2005) Garlic oil and DDB, comprised in a pharmaceutical composition for the treatment of patients with viral hepatitis, prevents acute liver injuries potentiated by glutathione deficiency in rats. Chem Biol Interact 155, 82-96

34. Lang A, Lahav M, Sakhnini E, et al. (2004) Allicin inhibits spontaneous and TNF-alpha induced secretion of proinflammatory cytokines and chemokines from intestinal epithelial cells. Clin Nutr 23, 1199-1208.

35. Son EW, Mo SJ, Rhee DK, et al. (2006) Inhibition of ICAM-1 expression by garlic component, allicin, in gamma-irradiated human vascular endothelial cells via downregulation of the JNK signaling pathway. Int Immunopharmacol $\mathbf{6}$, 1788-1795.

36. Ban JO, Oh JH, Kim TM, et al. (2009) Anti-inflammatory and arthritic effects of thiacremonone, a novel sulfur compound isolated from garlic via inhibition of NF-kappaB. Arthritis Res Ther 11, R145.

37. Takeda K \& Akira S (2005) Toll-like receptors in innate immunity. Int Immunol 17, 1-14.

38. Youn HS, Lim HJ, Lee HJ, et al. (2008) Garlic (Allium sativum) extract inhibits lipopolysaccharide-induced Toll-like receptor 4 dimerization. Biosci Biotechnol Biochem $\mathbf{7 2}$ $368-375$.

39. Clement F, Pramod SN \& Venkatesh YP (2010) Identity of the immunomodulatory proteins from garlic (Allium sativum) with the major garlic lectins or agglutinins. Int Immunopharmacol 10, 316-324.

40. Iqbal M, Philbin VJ, Withanage GS, et al. (2005) Identification and functional characterization of chicken toll-like receptor 5 reveals a fundamental role in the biology of infec- tion with Salmonella enterica serovar typhimurium. Infect Immun 73, 2344-2350.

41. Karpala AJ, Lowenthal JW \& Bean AG (2008) Activation of the TLR3 pathway regulates IFNbeta production in chickens. Dev Comp Immunol 32, 435-444.

42. Hassan ZM, Yaraee R, Zare N, et al. (2003) Immunomodulatory affect of R10 fraction of garlic extract on natural killer activity. Int Immunopharmacol 3, 1483-1489.

43. Morioka N, Sze LL, Morton DL, et al. (1993) A protein fraction from aged garlic extract enhances cytotoxicity and proliferation of human lymphocytes mediated by interleukin-2 and concanavalin A. Cancer Immunol Immunother 37, 316-322.

44. Kyo E, Uda N, Ushijima M, et al. (1999) Prevention of psychological stress-induced immune suppression by aged garlic extract. Phytomedicine 6, 325-330.

45. Liu CT, Su HM, Lii CK, et al. (2009) Effect of supplementation with garlic oil on activity of Th1 and Th2 lymphocytes from rats. Planta Med 75, 205-210.

46. Zamani A, Vahidinia A \& Ghannad MS (2009) The effect of garlic consumption on Th1/Th2 cytokines in phytohemagglutinin (PHA) activated rat spleen lymphocytes. Phytother Res 23, 579-581.

47. Ghazanfari T, Hassan ZM, Ebtekar M, et al. (2000) Garlic induces a shift in cytokine pattern in Leishmania majorinfected BALB/c mice. Scand J Immunol 52, 491-495.

48. Locksley RM, Killeen N \& Lenardo MJ (2001) The TNF and TNF receptor superfamilies: integrating mammalian biology. Cell 104, 487-501.

49. Schneider K, Kothlow S, Schneider P, et al. (2004) Chicken BAFF-a highly conserved cytokine that mediates B cell survival. Int Immunol 16, 139-148.

50. Ittah M, Miceli-Richard C, Lebon P, et al. (2011) Induction of $\mathrm{B}$ cell-activating factor by viral infection is a general phenomenon, but the types of viruses and mechanisms depend on cell type. J Innate Immun 3, 200-207.

51. Nduati E, Gwela A, Karanja H, et al. (2011) The plasma concentration of the B cell activating factor is increased in children with acute malaria. J Infect Dis 204, 962-970.

52. Ragheb S, Li Y, Simon K, et al. (2011) Multiple sclerosis: BAFF and CXCL13 in cerebrospinal fluid. Mult Scler 17, 819-829.

53. Yamanishi H, Kumagi T, Yokota T, et al. (2011) Clinical significance of $\mathrm{B}$ cell-activating factor in autoimmune pancreatitis. Pancreas 40, 840-845.

54. Janda A, Rensing-Ehl A, Eibel H, et al. (2011) Elevated serum BAFF levels in patients with autoimmunity and lymphoproliferation. Scand J Immunol 74, 518-519.

55. Bar-Shira E \& Friedman A (2006) Development and adaptations of innate immunity in the gastrointestinal tract of the newly hatched chick. Dev Comp Immunol 30, 930-941.

56. Poh TY, Pease J, Young JR, et al. (2008) Re-evaluation of chicken CXCR1 determines the true gene structure: CXCLi1 (K60) and CXCLi2 (CAF/interleukin-8) are ligands for this receptor. J Biol Chem 283, 16408-16415.

57. Martins-Green M \& Feugate JE (1998) The 9E3/CEF4 gene product is a chemotactic and angiogenic factor that can initiate the wound-healing cascade in vivo. Cytokine 10, $522-535$.

58. Rahman K (2001) Historical perspective on garlic and cardiovascular disease. J Nutr 131, 977S-979S. 